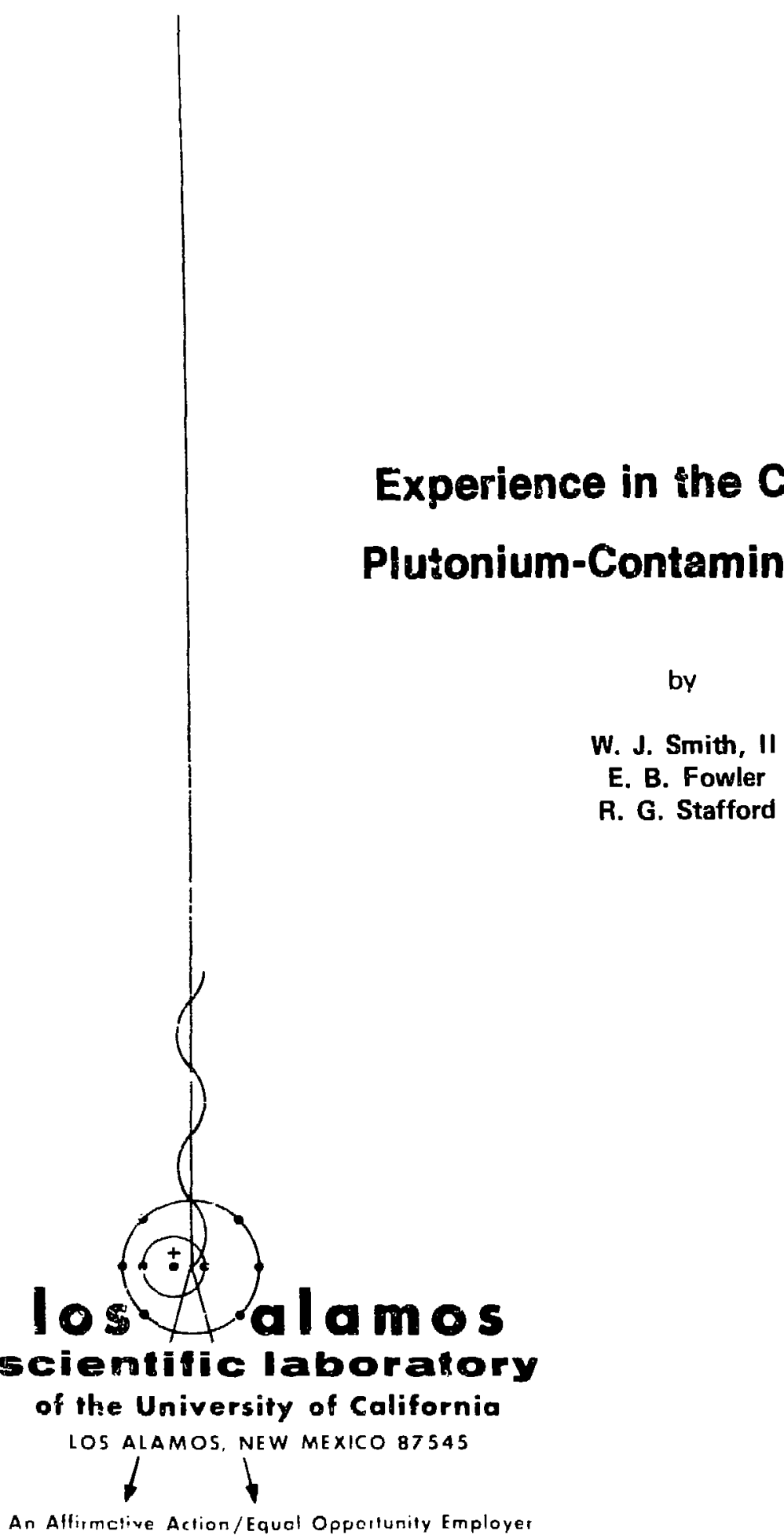

Issued: March 1977

\title{
Experience in the Cleanup of Plutonium-Contaminated Land
}

W. J. Smith, II

E. B. Fowler

R. G. Stafford 
Printed in the United States of America. Avalable from National Technical Information Service

L.S. Deparment of Cominerce

5285 Port Royal Road

Springficld. VA 22161

Price: Printed Copy $\$ 3.50$ Microfiche $\$ 3.00$

This repurt wat prepared as an arcuunt of wurk apunoored

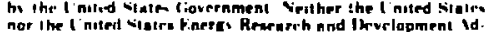

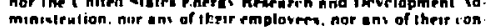

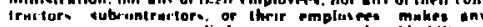

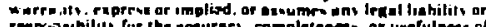

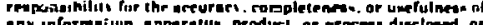

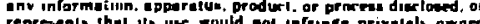

represers 


\title{
EXPERIENCE IN THE CLEANUP OF PLUTONIUM-CONTAMINATED LAND
}

\author{
by \\ W. J. Smith, II, E. B. Fowler"and R. G. Stafford"-
}

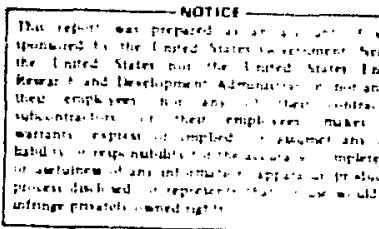

\begin{abstract}
During the summer of 1974 , two accidental releases from a radioactive liquid-waste line at the Los Alamos Scientific Laboratory (LASL) resulted in plutonium contamination of a emall area of lond, a portion of a Laboratory parking lot, and a strip along an adjacent street. This report documents the immediate control actions and radiation surveys made in response to these leaks, and the subsequent exhumation and decontamination processes, including the physical operations, operationil health phy sics, and soil sample enalyses. The cost and results of the decontamination and restoration are also covered.
\end{abstract}

\section{INTRODUCTION}

The term "cleanup," as defined for this report. means the removal and proper disposal of radioactive materials trum a contaminated site. Impicit in this definition is the existence of a contamination level below which the area is considered clean, and a prescribed means for measuring this level. For the operations described in this report. the background gross-alpha radioactivity level of local soils was used as the cleanup criterion. A zinc sulfide $\left(\mathrm{Z}_{\mathrm{n}} \mathrm{S}\right)$ alpha scintillation system was used in conjunction with soil radionuclide chemical analyses to determine the effectiveness of the cleanup activities.+

\footnotetext{
"LASL Group H-8, Environmental Studies "LASL Group H-1, Health Physics

+Each instrument and analytical procedure is described in Appendix A.
}

Radivactive liquid wast es from several areas of the Los Alamos scientific Laboratory (LASL) flow through collertion lines to a lift station. from which they are periodically pumped to a liquid waste treat nent facility. The pipeline from the lift station has iwo major segments. The first is a cast-iron force main through which the waste is purnped to a high point in the system. The second is a vitrified ciaytile. gravity-flow line which descends to the waste treatment facility. The system collects wastes of variable radionuclide content; however, in recent years wastes have contained predominantly. ${ }^{25} \mathrm{Pu}$, with lesser concentrations of ${ }^{230} \mathrm{Pu},{ }^{80.00} \mathrm{Sr}$, and ${ }^{137} \mathrm{Cs}$. In 1974, average yearly concentrations in the waste were $3 \times 10^{\circ} \mathrm{dis} / \mathrm{min} / \ell$ for gross alpha and $5 \times 10^{5}$ $\mathrm{dis} / \mathrm{min} / \ell$ for gross beta: typical volumes were about $3 \times 10^{\circ} \mathrm{\ell} /$ month. Figure 1 is a map snowing the ma jor features of this system.

In the past, the pipeline has been subject to surveillance at irregular intervals by personnel walking its length and monitoring the cleanout risers and

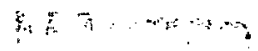




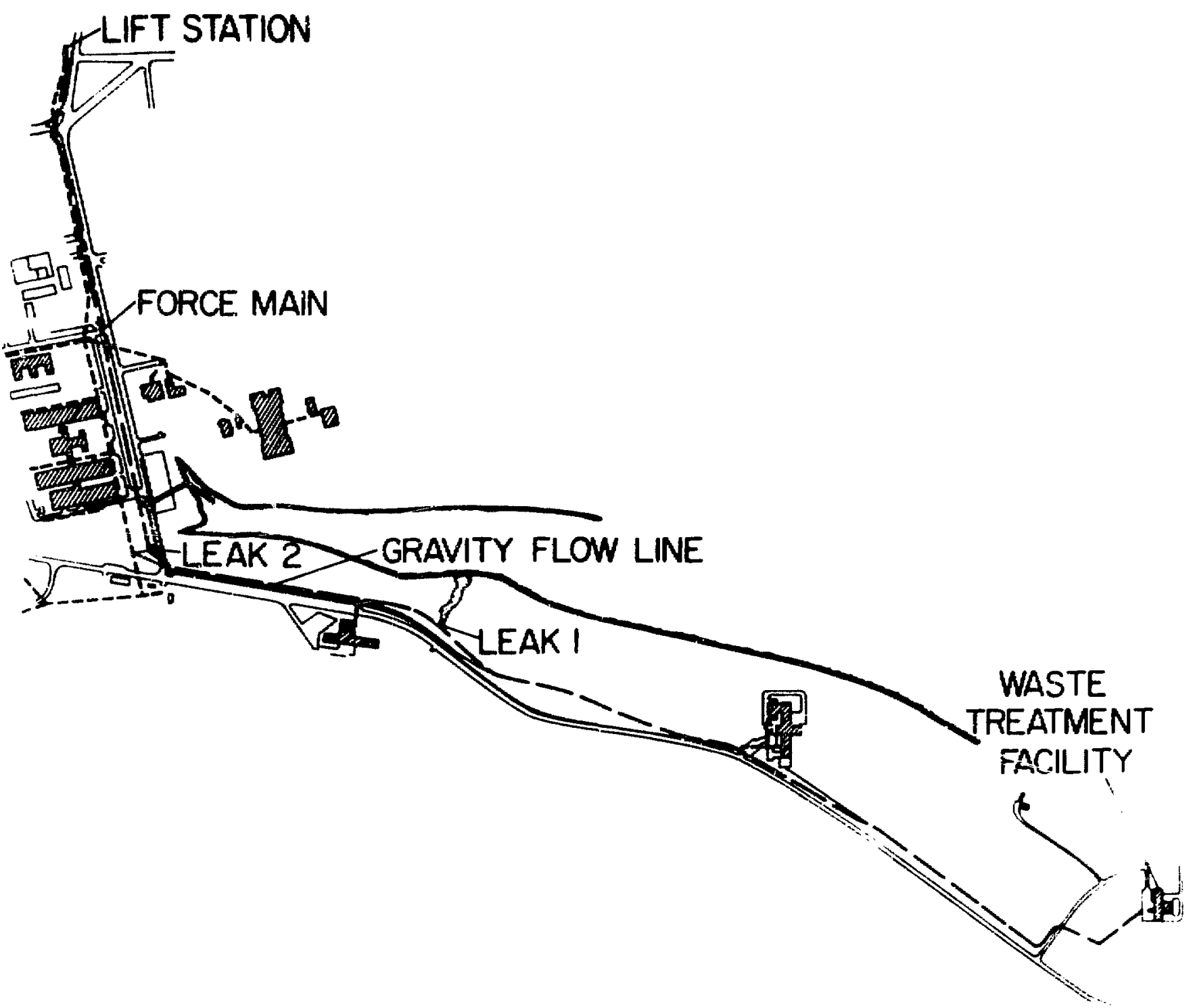

Fig. I.

A portion of the liquid uaste handling stserm at Lets Alames 
(Hi)s. Surseillance had been conducted less than a vear before the discovery, in late June 1974, of damage 11 cleanout risers near a new construction ul. Nin releases resulted from the damage, but its discovery prompted a subsequent inspection of the ertire line that resulied in a July 9, 1974, discovery if a leak at a separate cleanout riser (indicated as "1.ak 1," in Fig. 11. This leak was the first observed trum this line since its construction in 1962.

Mithin two days of the discovery of the leak, the affected length of line was unearthed and cleaned with s sewer rowter. A number of cracks were four.d in the line. and the leak was at tributed to plant rools entering and cloghing the line. A radiation survey of the vicinity indicated that the contaminated area was large enuugh to require an extensive excavation effort. Since the pipeline was now considered of questionable integrity fir prolonged use, it wus decided to proceed with a cleanup of a limited po:tunn of the area to permit installation of a replaciment gravily-thus line

Hy the end if August, a butt-welded polyethylene waste line had been installed. and on September :3, [!T.4. it was subjected to a pumping test. The flow capacity of the new line was inadvertantly exceeded during the test. causing waste to back up and flow rut il a munhole at the junction of the cast-iron and pulserholene lines. The ocation of the point if wertlow is marked as "leak 2" in Fig. 1. Leak 2 con. taminated a portion of a street and parking lot, and a itorm drain leading is a nearby canyon. Within the dias. the comtaminarion on paved areas was fixed by applying a laver of asphalt, and the canyon thow wrs blucked by an earthen dam. A small area around the manhule was excavated. hackfilled with clean soil. and surrounded with an earthen berm as a precar. tion against subsequent oyerflows. The efforts to contain and prevent the spread of contamination trom leak ? were followed by excavations to clean up the contaminated material, and restoration of the affected areas was begun by the end of September.

Immediat ely thereafter, attention was given to the excavation of the major portion of the area contuminated by Leak 1 . This work was completed by late (October and restoration of the area was finished in mid-Nivember 1974 .

\section{THE CLEANUP MISSION}

Leak I was located in an area which could be isolated for controlled access. Soil, tuff the priniipal rock-type outcrop occurring in the area, consisting of a welded volcanic ash), and vegetation were contaminated. Time was needed, and could afely be taxen, to make exiensive preliminary surveys and to design an effective cleanup. The cleanup missiun was defined in three parts:

1. Determine the extent, in three dimensions, of the contaminated land:

2. clean up the area to the level of gross-alpha radioactivity of surroinding, uncrintarninated land:

and

3. determine the plutonium inventory asscciated with the release.

Leak 2 was associated with a Laboratory parking lot and a road used by the general public, and re. quired immediate actior. The urgency of the situation required positive action without the benefit of extensice preliminary work. The mission was again defined in three steps:

1. Clean up the area observed to be contaminated by the liquid radioactive waste. plus a $2.3 \mathrm{~m}$ safety zone on all sides:

2. effect a contamination level not exceeding the gross-alpha level found beneath the paved road and parking lot: : ad

3. restore the area with the least delay consistent with a thorough and complete cleanup.

\section{IMMEDIATE CONTROL ACTIONS}

The immediate responses to both of the leak incidents were: 111 to establish safety measures for the protection of personnel and the public, (2) to perform radiation surveys to determine the extent and severity of the contamination, and $(3)$ to prevent the migration of the contamirant by containment actions until cleanup procedures could be started. 


\section{A. Leak 1}

As people would not normally trequent the area of Leak 1 , it was deemed sufficient to fence the area and post it with warning signs. The first barrier was erected on the day the leak was disccvered; the perimeter was subsequently adjusted as radiation surveys more accurately determined the extent of the area. Health physics measures to ensure adequate personnel protection included using booties, coveralls, and gloves for workers in the area, and monitoring hands, shoes, and clothing when workers left the area. Nose swipes were taken for analysis for inhaled radionuclides. Four hi-vol continuous air samplers were set in operation around the periphery on the day following the discovery of the leak. A portable, low-volume air sampler was used as an operational air monitor close to the breathing zone of workers engaged in the preliminery excavation work.

The survey of the cleanout riser, which disclosed the leak, was made with an alpha survey instrument which indicated aipha radioactivity up to 50000 counts/min. Up to 10000 counts/min were observad as far as $10 \mathrm{~m}$ from the riser, along the natural drainage path of the area. Preliminary soil samples taken at that time and analyzed subsequently by rough chemical procedures indicated 10000 to $130000 \mathrm{dis} / \mathrm{min} / \mathrm{g}$ of gross alpha radioactivity.

Initial investigations following the discovery of the leak. were intended to pinpoint the cause of tine leaking riser and to determine whether the source of the leak was below the surface or through the riser cap. A plastic bag was secured over the clean-out riser and waste was pumped into the line. About $20 \mathrm{mir}$. later, liquid was observed at the top of the riser and in the plastic cover. This required at least $0.6 \mathrm{~m}$ of hydrostatic head in the line, indicating an cosstruction downstream in the gravity-flow line.

It was observed during the test that the riser pipe was loose. Excavation revealed a broken joint from which waste also was seeping. The joint was repaired and a small sewer "snake" was introduced into the line in order to remove the obstruction causing the leak. The snake removed some roots in the line, and a large sewer rooter was later used to clean the line over its evitire lent ${ }^{\text {th }}$. An excavated trench along the waste line extended for approximately $15 \mathrm{~m}$ up. stream and $10 \mathrm{~m}$ downstream of the leak. Data showing the radioactivity observed on the wails of the trench are presented in Tables 1 and 11 . A total of $f$ $\mathrm{m}^{\mathrm{s}}$ of cont aninated soil was removed from the area and buried in twenty-nine $210-\ell$ steel drums.

Plastic-lined cardboard cartons, $210-\ell$ mild steel drums, and dump trucks were used for collection of radioactive materials at various stages in the cleanup operations. The selection was generally based on the mode of excavation; manual excavation made use of the foimer two containers, while mechanized excavation required dump trucks as containers. In generai, although not aiways, steel drums were used for the higher radioactivity naterials removed in manual excavations.

Surveys were made of the land surface around the leak using a FIDLER* probe and the Los Alamos Field Pulse Height Analyzer (LAFPHA). The observed radioactivity profiles are shown on the Fig. 2 map of the area.

Considering the time required for excavation of the contaminated area indicated by this survey and the questionable integrity of the waste line for prolonged use, it was proposed tha a limited cleanup be undertaken sufficient for the laying of a new waste line. These cleanup procedures are discussed in detail in Section IV.

Since there was no apparent hazard from the soilbound radioactivity of Leak 1 , no immediate actions for imposing additional containment were taken. Transport of radionuclides away from the leak occurred in two phases: first the liquid waste percolated through the soil until absorbed, and secondly the scil with its sorbed radionuclides was moved by summer rain runoff. Movement of the plutonium by wind resuspension was not discernable by continuous air sampling, presumably due to the moist condition of the soil during the late summer.

\section{B. Leak 2}

The location of Leak 2 required immediate action for the protection of personnel and the public. Activities were concerned primarily with the redirection of people and vehicles, removal of the released liquid, and coniainment of any residual radioactivity. The waste primarily flowed alon 5 a curb gut ter provided for storm runoff, and puddled in the

*Field Instrument for Detecting Low-Energy Radiatoon. 
TABLE I

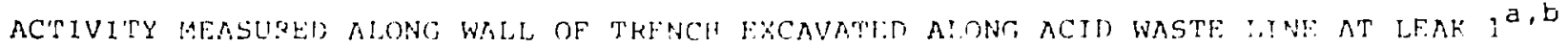

\begin{tabular}{|c|c|c|c|c|c|c|c|c|c|c|c|c|c|c|c|}
\hline & & & & & No & h & & & & & Clean & ut $r \perp s$ & ser. & - Leak & 1 \\
\hline iround Surface & - & - & - & - & - & - & - & - & $2 \mathrm{k}$ & $!$ & $1.5 \mathrm{k}$ & $1.5 k$ & & - & - \\
\hline $1 \mathrm{Et}$ & - & - & - & - & - & - & - & - & $2 k$ & $\vdots$ & $1.5 k$ & $1.5 \mathrm{k}$ & & - & .. \\
\hline $2 \mathrm{ft}$ & - & - & & - & - & - & - & - & $2.5 \mathrm{k}$ & 1 & $1 \mathrm{k}$ & $1.5 k$ & & - & - \\
\hline $2.5 \mathrm{ft}$ & - & $15 k$ & $20 k$ & $2 k$ & & - & - & - & $1.5 \mathrm{k}$ & & $1 k$ & $2 k$ & & - & - \\
\hline 3 ft (pipe level) & - & - & $100 \mathrm{k}$ & $15 \mathrm{k}$ & $15 k$ & - & - & - & $1 k$ & $!$ & $1 \mathrm{k}$ & $1 k$ & & - & - \\
\hline
\end{tabular}

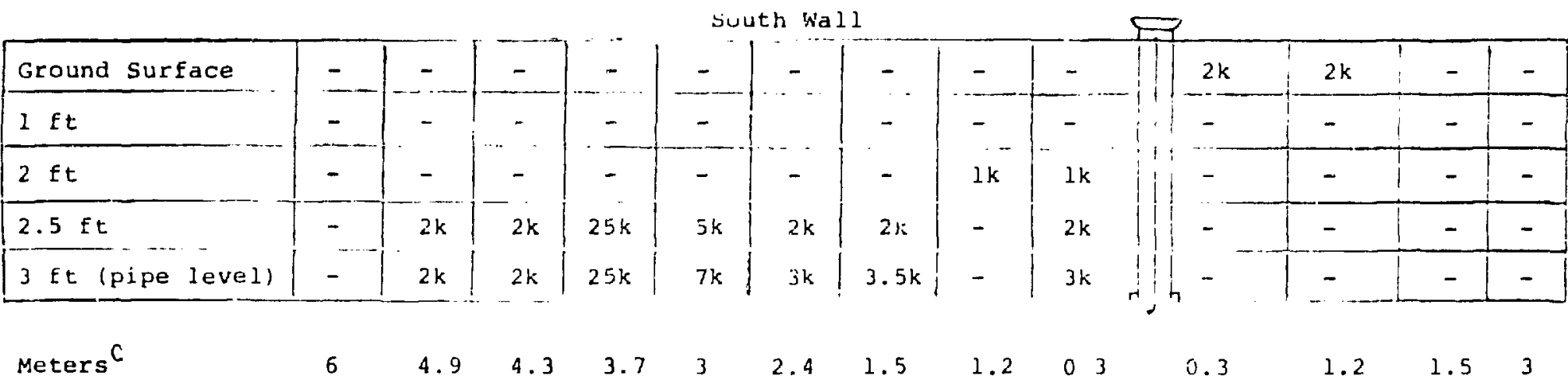

${ }_{\text {All }}$ readings are in counts/min on the alpha survey meter.

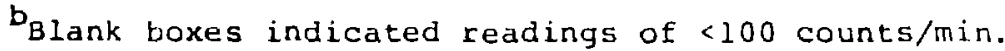

${ }^{C_{\text {Measured }}}$ up- and down-grade from the cleanout riser. 
TABLE II

ACTIVITY MEASURED AI,ONG WALL OF 'TKENCH EXCAVATILU ALOHG ACID WAS'LE I.INI: AT LEAK $1^{a, b}$

\begin{tabular}{|c|c|c|c|c|c|c|c|c|c|c|c|c|c|}
\hline \multicolumn{14}{|c|}{ North Wall } \\
\hline Ground Surface & 0.2 & 0.2 & 0.5 & 0.5 & 0.5 & 0.5 & 0.5 & 0.5 & 1.5 & 3.0 & 0.9 & - & - \\
\hline $1 \mathrm{ft}$ & 0.2 & 0.2 & 0.5 & 0.5 & 0.5 & 0.5 & 0.5 & 0.5 & 0.5 & 3.0 & 0.9 & - & - \\
\hline $2 \mathrm{ft}$ & 0.2 & 0.2 & 0.2 & 0.7 & 0.5 & 0.5 & 0.5 & 0.5 & 0.5 & 3.0 & 0.9 & - & - \\
\hline $2.5 \mathrm{ft}$ & 0.2 & 10 & 0.7 & 1.5 & 0.2 & 0.2 & 0.2 & 0.5 & 0.5 & 2.5 & 1.0 & - & - \\
\hline $3 \mathrm{ft}$ ( $\mathrm{pipe}$ level) & 0.2 & 40 & 45 & 8 & 1.0 & 0.5 & 0.5 & 0.5 & 0.5 & 1.0 & 0.7 & - & - \\
\hline
\end{tabular}

South Wall

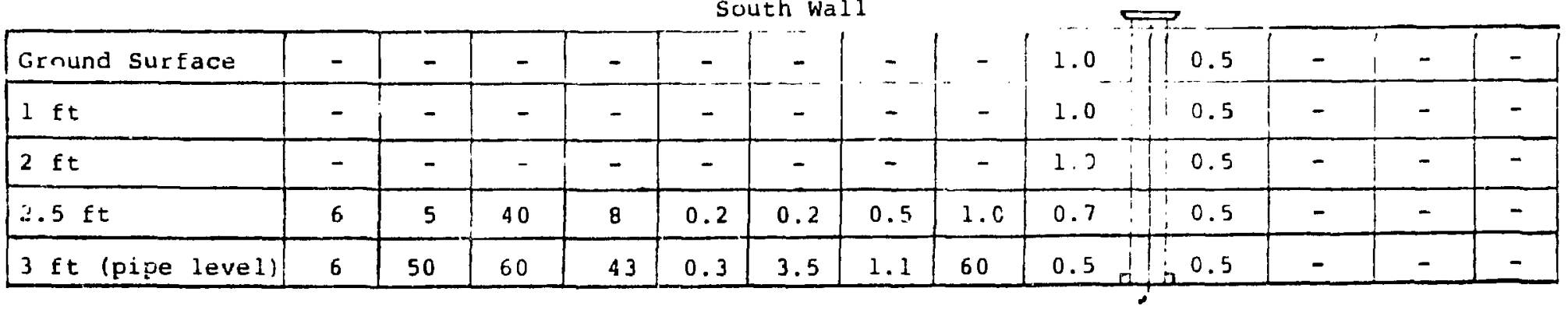

$\begin{array}{llllllllllllll}\text { Meters }^{c} & 6 & 4.9 & 4.3 & 3.7 & 3 & 2.4 & 1.5 & 1.2 & 0.3 & 0.3 & 1.2 & 1.5 & 3\end{array}$

all readings are in $\mathrm{mr} / \mathrm{hr}$ on the beta-gamma survey instrument.

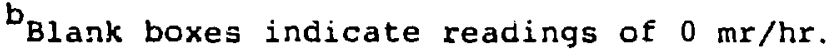

CMeasurd $\mathrm{zp}$ - and down-grade from the cleanout riser. 


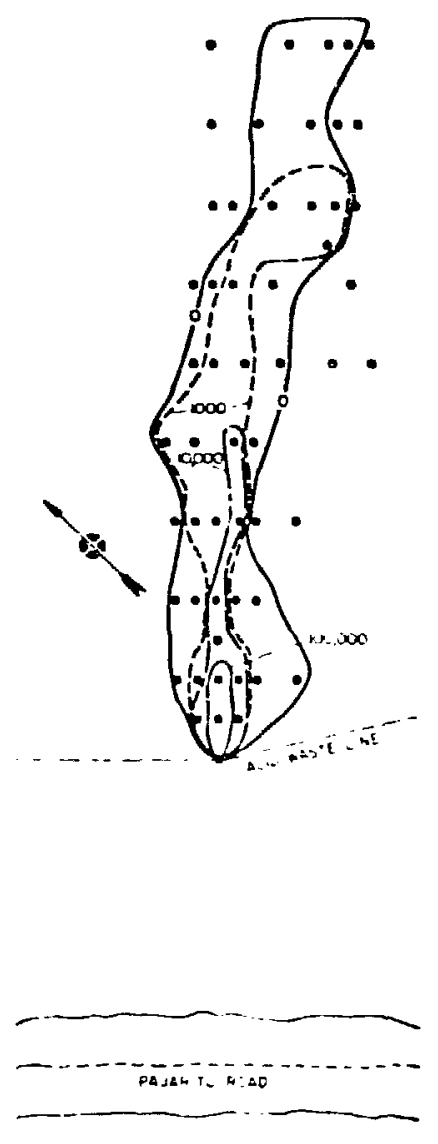

Fig. 2 .

FII)LER/LAFPHA surLey of Leak I. Values art net counts/min in $17 \mathrm{keV}$ channel. Points shot locations of some soil core and surface sample.s. entrance and exit to a Laboratory parking lot. A small puddle also formed in the entrance to a technical area adjacent to the parking lot. Move. ment through those areas was curleiled by closing the gate at the guard station and preventing vehicular movement into or out of the parking lot. suthbuind traffic along Diamond Drive was directed into the inner lane, providing a safety zone for workers and preventing accidental vehicle contact with the waste water in the gutter. A wooden ramp was constructed spanning the contaminated gutter, which permitted vehicles to leave the parking lot at the close of the business day. Pedestrians entering the area were routed along the far side of the street. Figure 3 is a map of the area of Leak 2.

Protective clothing was provided for personnel involved in cleanup operations. Other health physics measures included monitoring hands, shoes and clothing of personnel leaving the area, and taking nose swipes as a check for possible inhalation exposures.

Initial radiation surveys were coupled w . h actions to control and contain the released liquid waste. These efforts began with mopping and sweeping the water to prevent it from spreading. Subsequently, the standing liquid was absorbed with cheesecloth or collected using wet-dry vacuum cleaners and placed in $210-\ell$ drums. As the paved road and parking lot surfaces were dried, areas observed to have been contaminated were roped at a perimeter established using the elpha survey instruments. Two coats of hot asphalt mix were applied as a seal over the con. taminated paved surfaces. No radioactivity was detectable after application of the first coat.

An area immediately around the manhole from which th: woste was released was surveyed with both the alpha survey instruments and the FIDLER/LAFPHA System. Soil was excavated from that area to a depth of about $0.3 \mathrm{~m}$, and clean backfill was applied as a temporary containment for residual subsurface soil radioactivity. Data before and after the excavation are presented in Fig. 4. A total of $13.4 \mathrm{~m}^{\mathrm{a}}$ of conteminated absorbents and soil was ren:oved and buried in steel drums and plastic. lined cardboard cartons.

A portion of the released waste had been conducted through a storm airain into a nearby canyon. Concurrent with the above actions, efforts were applied to impounding the fluw through the canyon by 


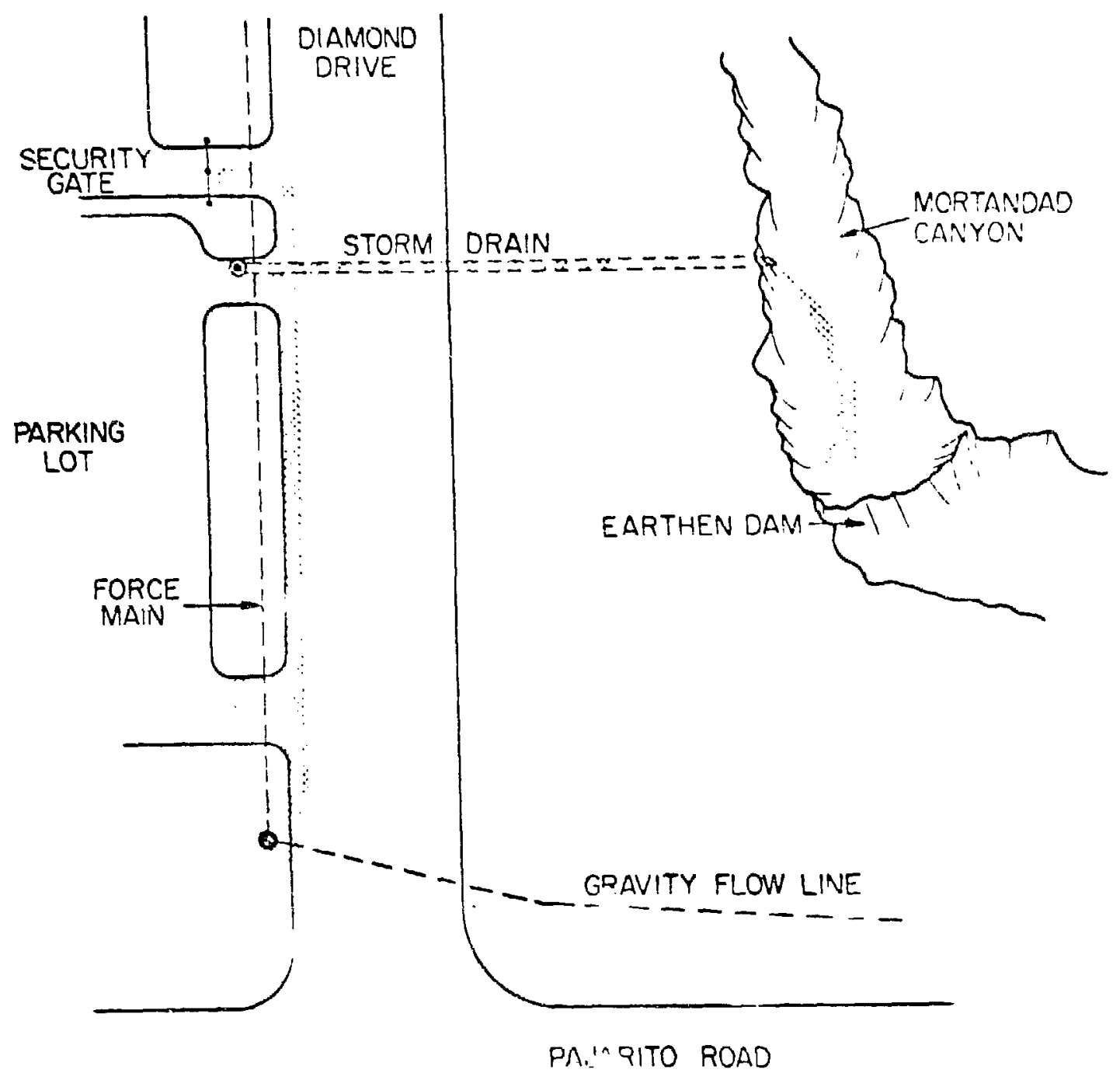

Fig. 3.

The area of leak 2.

constructing a small earthen dam a short distance below the drain's outfall. Surveys with alpha survey instruments indicated count rates of 800 to 1200 counts/min along the stream bed above the dam.

\section{EXCAVATION AND DECONTAMINA- TION PROCEDURES}

\section{A. Leak 1}

The full-scale cleanup of Leak 1 was effected in two siages. A small trench across the area was prepared for the laying of a temporary, butt-welded polyethylene waste line. The trench (approximately $12 \mathrm{~m}$ long and 1 to $4 \mathrm{~m}$ wide) was excavated by pick and shovel to depths of 30 to $100 \mathrm{~cm}$. The most highly contaminated sections of soil were removed; however, since both the old waste line and the temporary line are expected to be excavated when a proposed new line is installed, a complete cleanup was not attempted. A total of $43.4 \mathrm{~m}^{9}$ of soil was removed, packaged in plastic-lined cardboard cartons and buried. Figure 5 diagrams the area of the excavation and indicates levels of residual radionctivity. 

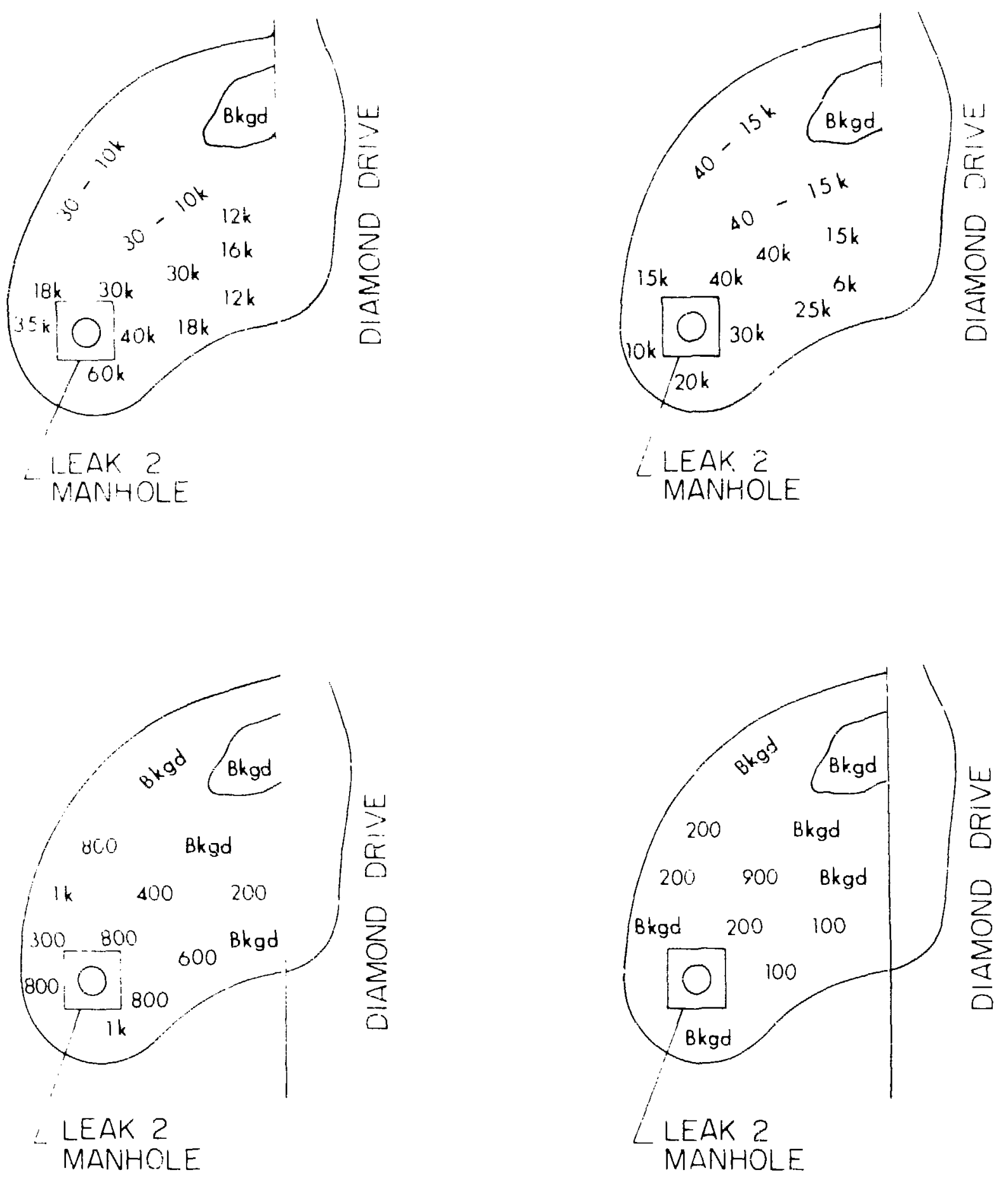

Fig. +

Leak 2 manhole area befure and after excacation. 


\begin{tabular}{|c|c|c|c|c|c|c|c|}
\hline Bkgd & 100 & 1000 & 3000 & 300 & Bkgd & Bkgd & Bkgd \\
\hline 100 & 7000 & 1000 & \\
\hline 400 & 1100 & 500 & \\
\hline
\end{tabular}

FINAL SAMPLES $(\mathrm{pCi} / \mathrm{g})$

\begin{tabular}{|c|c|c|c|c|c|c|c|}
\hline Bkgd & 50 & 50 & 100 & Bkgd & Bkgd & Bk.gd & Bkgd \\
\hline & & 100 & Bkgd & 150 & & & \\
\hline & & & Bkgd & 50 & & & \\
\hline
\end{tabular}

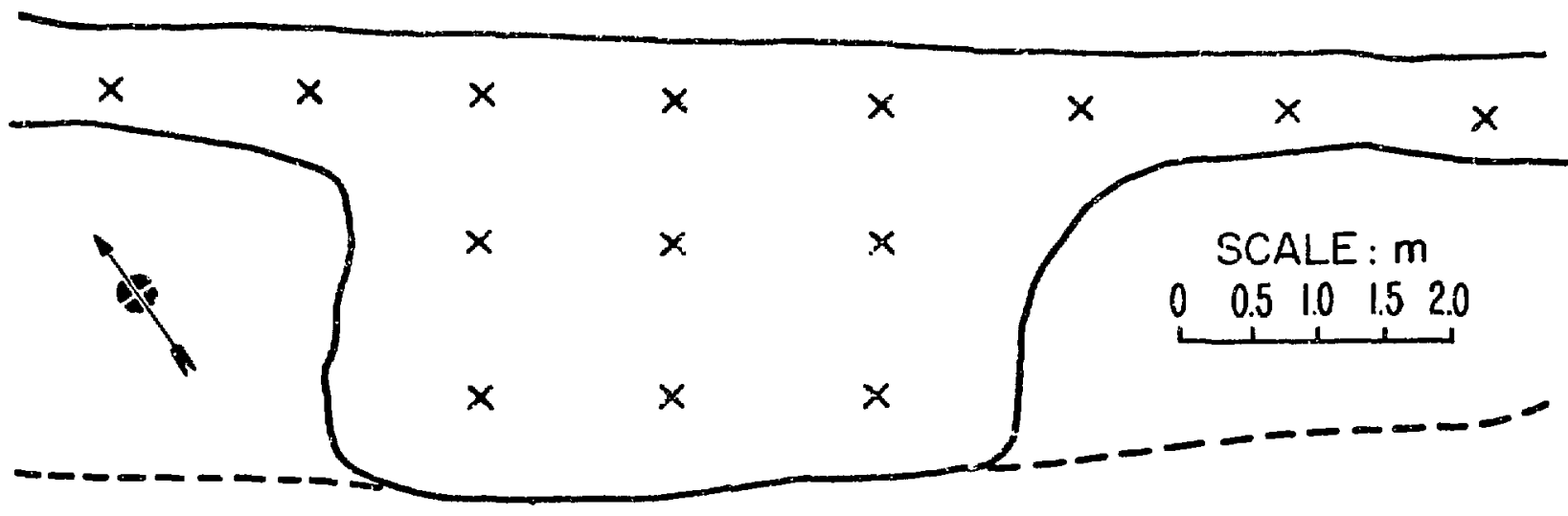

OLD WASTE LINE EXCAVATION 
The cleanup of the major portion of Leak I was begun after the installation of the temporary waste line, and the vccurrence and cleanup of Leak 2. A preliminary analysis was made of surface soil samples, soil cores, and background soil samples. Surfece suil samples were taken using a location pattern based on the preliminary FIDLER/LAFPHA survey. Sampling procedures and data are described in Appendix $B$.

The results of soil core sample analysis indicated that the radioactivity decreased rapidly with depth rear the source of the leak, but that substantial radioactivity could be expected at depths of 60 to 100 $\mathrm{cm}$. At distances of $20 \mathrm{~m}$ and more from the leak the radioac vity was found to be more uniformly distributed in the soil profile, presumably due to its having been laid down as silt deposits from the runoff of frequent summer storms.

Background surface soil samples were taken at several distant points within Los Alamos County. A number of background samples were also taken at distances of a few hundred meters from the cor:taminated area. No background cores were taken. The average value obtained for the gross-alpha radioactivity of the background samples was defined as the level to which the area wouid be cleaned. With the $\mathrm{ZnS}$ system, the defined level equaled $\mathrm{a}$ measurement of $<25 \mathrm{pCi} / \mathrm{g}$; for the acid-leaching chemistry procedure the level was found to be $<12$ $\mathrm{pCi} /{ }_{n}$.

A map of Leak 1, showing isopleths of concentration as determined by soil samples, is given in Fig. 6. The periphery of the area was determined according to the background for area soils and $r \in$ presented the minimum area to be excavated in fulfillment of the designated mission. The minimum depth to be cleaned was estimated as $60 \mathrm{~cm}$ or mare on the basis of soil cores showing substantial radivactivity ut their $30 \mathrm{~cm}$ maximum depth. The actual depth of the excavation was to be determined by samplirg the newly exposed surfaces after each excavation.

Calculations of the quantity of released plutonium were made using Fig. 6. soil core data, and data on the volumes and concentrations removed in the original excavations of the waste line and for the tempotary line. Estimates using various methods of averaging land areas, soil concentations, and summing over depth profiles ranged from 150 to $300 \mathrm{mCi}$, which was believed to be satisfactory considering the uncertainties involved in the measurements and es. timates.
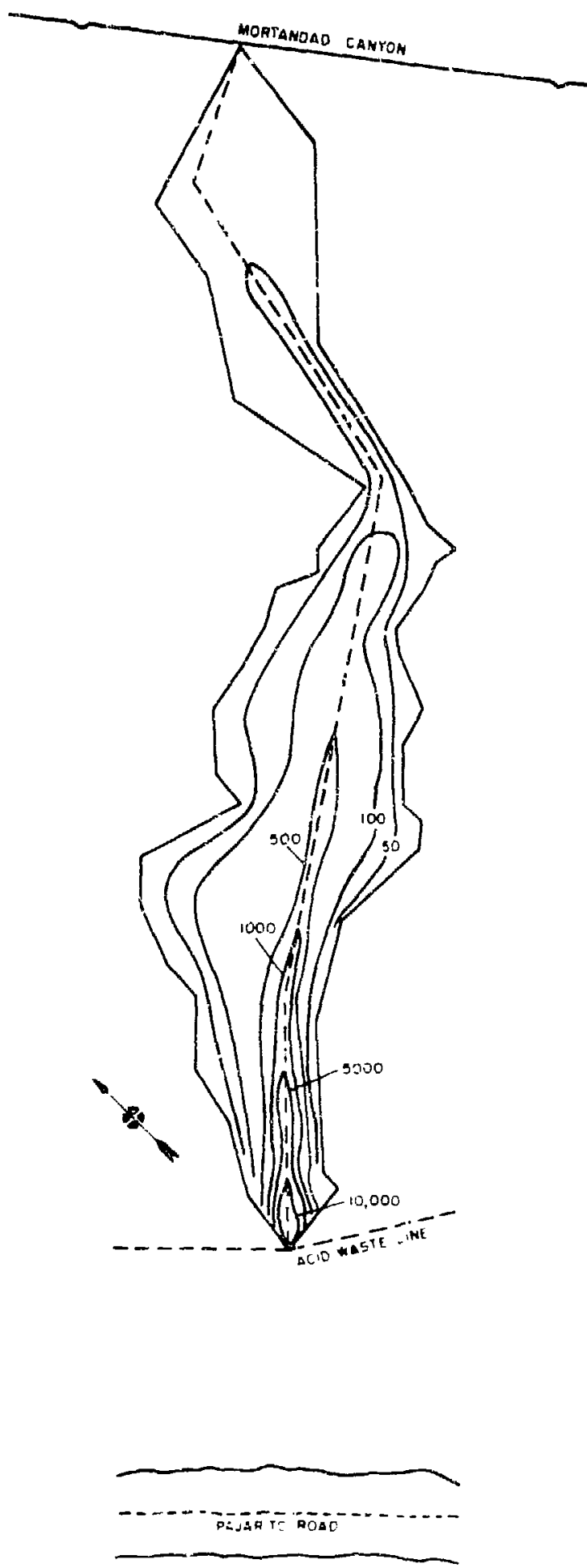

Fig. 6.

Soil sample data map of Leak 1. Values are pCilg. Perimeter line is at background gross. alpha level. 
The sleanup was accomplished using heavy squipment, i.e., front-end loaders and dump trucks. Work progressed from the least contaminated areas inward to the more contaminated areas, with extreme care being taken to ensure that no contamination was carried outward by the moving vehicles. The dump truck beds were sealed with heavy plastic sheeting: scil was loaded no higher than the top of the bed, and the load was covered with heavy tarpaulins for the trip to the waste disposal area. Convoys of several trucks were escorted by radio-equipped vehicles ma!ntaining a speed of $35 \mathrm{mph}$. After disposing of the losd, each vehicle was monitored externally for contamination and decontaminated, if necessary, before its return to the work sice.

As the neavy equipment cieaned out an area and moved further in ward, healt th physics monitors and soil sampling personnel followed. Each area was thoroughly surveyed with the alpha survey instruments and the FIDLER/LAFPHri. Soil samples from the fresh surface were taken on the original sampling pattern and analyzed using the $\mathrm{ZnS}$ system and the chemical analysis procedures.

Three passes of the equipment, cver consecutively smaller areas, were made as soil analyses verified the cleanup of some areas and detected residual con. tamination of others. The maximum depth excavated was $1-1.5 \mathrm{~m}$ at the most higl:ly contaminated end of the area. A final decontamination was made of four small areas by pick and shovel; contaminated liquid had seeped into crevices of the underlying rock and had become absorbed by the clay deposits in these areas. A total of about $233 \mathrm{~m}^{3}$ of soil was removed in 74 truckloads and baried.

$\mathrm{Hi}$-vol air samplers were operated during the entire cleanup, but indicated no airborne radioactivity above normal background. All personnel wore protective clothing and were monitured for contamination upon leaving the site.

\section{B. Leak 2}

Cleanup of Leak 2 began the day following its occurrence. A collection and pumping system was set up to allow flushing of the contaminated storm drain and collection of the water for pumping to tank trailers for later processing as liquid waste. The drain was flushed three times using a dispersant followed by water. The initial flushiniz carried a large amount of the alpha contamination out of the drain: less was observed in samples tyken from suhsequent flushings. Samples of the drain water taken on the following days showed background levels of grossalpha radinactıvity.

Inicial canyon soil and sediment samples showed that the waste haci moved about $50 \mathrm{~m}$ down the canyon to where the earthen cuntainment dam had been erected on the day of the leak. The cleanup of the canyon area also hegan the day following the leak. while the water from the storm crain was being contained. Prior to excavation, the stream channe! was filled with bentonite to absorb standing water. The stream bed was then excavated using a backhoe and front-end loader. All alluvial material showing radioactivity above background was removed, for a tot.:! of about $192 \mathrm{~m}^{3}$ of waste materials iransported to the radioactive waste dump in 35 truck loads.

The aim for the decontamination of the paved areas was initially stated as the gross-8.lpha level determined from a sample of base-course material currently used in road construction. However, when excavation was begun, it was found that the basecourse underlying the excavated pavement had significantly lower background radioactivity (presumably due to the absence of fallout radionuclides). Thus the gross-alpha background of that material was used as the cleanup criterion.

The pavement to be excaveted was cut, outside of the sealed are $九$, using a cutting edge attached to the blade of a road grader. The asphalt was cut to the depth of the base-course, and front-end loaders were used to break up and lift out the pavement. Activity progressed along Diamond Drive from both ends, with the areas where liquid formed puddles in the parking lot entrances taken out as they were encounterad. About $176 \mathrm{~m}^{3}$ of material were removed in 46 truck loads and buried.

As pavement was removed and loaded into the trucks for disposal. all newly exposed surfaces were monitored with the alpha survey instruments. Radioactivity was found only on one segment of curbing; that segment was subsequentily removed. Following the imoval of all pavement, a thorough survey was made with the FIDLER/LAFPHA system. io radioactivity above background was ubservert in or around the excavated area. Samples were then taken of the exposed bait course, and unalysis of these by the $\mathrm{ZnS}$ systen and chemical procedures revealed no radioactivity above the decontamination criterion. 


\section{RESTORATION NIETHODS}

Restoration of the Leak 1 excavation site consisted of backstilling to grade with top soil and reseeding the land with native grass species. The reseeding was sticcessful. producing a growth comparable to that of similar open areas and preventing any extensive erosion of the new soil.

Restoration of Leak 2 was predominantly a repaving project. This effort required replacing curbs and pavement and took about three weeks. No restoration actions were taken for the small section of canyon that was involved, since it had been previously disturbed and was not adversely affected. The area around the manhole remained enclosed in an eurtinen berm paved with asphalt as a temporary safety measure for protection against any future leaks until engineering measures could be taken to prevent waste overilow. These measures included instrumentation to detect a rise of the liquid level in the manhole, with resulting shut cown of the pumping operations. A secondary safeguard was the installation of piping to return excess waste to the waste holding tank.

\section{EXPOSURES}

All evidence indicates that there were no exposures to the public or working personnel attributable to these leaks. Air sampies were taken continucusly at both sites until the cleanup operations were completed; no positive alpha radioactivities were detected. Monitoring of personnel leaving the contaminated areas was rigidly enforced, but no positive alpha radioactivities were detected on shoes, coveralls or hands of the personnel. In the early cleanup period, several booties were found to have alpha contamination ranging from $500-2000 \mathrm{c} / \mathrm{m}$. A totai of 155 nose swipes were taken in conjunction with all operations for Leak 1 , and 89 were taken as a result of Leak 2; all nose swipes were negative for alpha contamination.

\section{COSTS}

A breakdown of the total costs for each of the two incidents is given in Table III. The figures are estimates, based on the best available information. Each heading includes costs for manpower, supplies, and materials, but does not include baseline items such as required instrumentation and laboratory facilities.
TABLE III

\begin{tabular}{|c|c|c|}
\hline EST IMATED & costs & \\
\hline & $\begin{array}{c}\text { Leak } 1 \\
\text { SK } \\
\end{array}$ & $\begin{array}{r}\text { Letak } 2 \\
-\$ K \\
\end{array}$ \\
\hline $\begin{array}{l}\text { Clean/Repait } \\
\text { Waste l.liae }\end{array}$ & 5.4 & --- \\
\hline Sptll Contalument & $\cdots$ & 12.3 \\
\hline H.P. Survelllance & 13.0 & 5.1 \\
\hline $\begin{array}{l}\text { Environmental } \\
\text { Surveillance }\end{array}$ & 4.6 & 1.2 \\
\hline $\begin{array}{l}\text { Enviromuental } \\
\text { Sample Andysis }\end{array}$ & 14.6 & 8.6 \\
\hline $\begin{array}{l}\text { Escavations and } \\
\text { Restoration }\end{array}$ & 10.4 & $1 y .0$ \\
\hline Waste D1sposal & 1.6 & 1.8 \\
\hline TOTAL & 49.6 & 48.0 \\
\hline
\end{tabular}

\section{RESIDUAL ACTIVITY}

\section{A. Leak 1}

Two incompletely cleaned areas remain. Some plutonium contamination remains beneath the original clay-tile waste line for a length of about 35 $\mathrm{m}$; contaminant levels of $30 \mathrm{nCi} / \mathrm{g}$ might be found in certain portions of that area. (This value was roughly estimated from the data of Table I, using arbitrary assumptions of a $2 \pi$ geometry and a $50 \%$ detection probability for an alpha particle emitted in the proper direction.) Small portions of the trench excavated for the installation of the temporary polyethylene line are known to have plutonium concentrations of as much as $0.05 \mathrm{nCi} / \mathrm{g}$ (from Fig. 5). Both of those areas currently exist under clean backfill at a depth of 1 to $2 \mathrm{~m}$, and will be subject to further cleanup when a proposed new waste line is built.

The major portion of the Leak 1 area is well documented as being at or below the ambient soil background. Radioactivity was removed by pick and shovel from three small rock fractures and clay deposits in the last pass over the area. At one small fracture, $7.5 \mathrm{~m}$ from the leak, radioactivity in the final sample was about $30 \mathrm{pCi} / \mathrm{g}$; all others were at background. The area is now covered by 1 to $2 \mathrm{~m}$ of clean backfill. 


\section{B. Leak 2}

The only known residual contemination is that remaining around the manhole (see Fig. 4), where a complete cleanup was not attempted. Gross-alpha concentrations in soil or: the order of $15 \mathrm{nCi} / \mathrm{g}$ (roughly estimated) may still exist at isolated points below the clean earth backfill and asphalt cover. However, data indicate that the area is, in general, below $0.5 \mathrm{nCi} / \mathrm{g}$ gross alpha.

The cleanup of the roudway and puddle areas is well documented as having been complete. Indeed, the average alpha radioactivity after cleanup was find to be lower than the ambient suil backgrouml. It may be expected that some residual radioactivity rould have been bound within the storn drain leading to the canyon, but the contamination remaining in this culvert, if any, is such that effluent water is at background levels for alpha radioactivity. The strip of narrow strearn bed which was contaminated was sampled after cleanup and the radiouctivity content was found to be background.

\section{APPENDIX A INSTRUMENTATION AND ANALYTIC PROCEDURES}

The characteristics and applications of the instruments and sample analysis procedures used in the Leak 1 and 2 cleanups are briefly described here, in order of their mention in the text.

\section{A-1. Zinc Sulfide (ZnS) Alpha Scintillation Probe}

This system, consisting of a zinc sulfide alpha detector and single-channel analyzer, was used as the main means for rapid alpha radioactivity analysis of bulk soil samples. Soil preparation consisted of mixing, breaking apart of aggregates, and drying under heating lamps. Sample counting was done using $1.5 \cdot \mathrm{cm}$ high by $10-\mathrm{cm} \cdot$ diam petri dishes filled with soil. System calibration was made with a standard petri dish filled with a prepared $2 \mathrm{nCi} / \mathrm{g}$ $\left({ }^{230} \mathrm{Pu}\right)$ soil sample. Samples were counted for $5 \cdot \mathrm{min}$ periods, and the detection sensitivity was found to be about $25 \mathrm{pCi} / \mathrm{g}$ above ambient gross-alpha background at the $99.7 \%$ confidence level.

\section{A-2. Chemical Analysis}

Two different chemical analyses were performed. The first, an "acid leaching " process, was performed on almost all of the soil samples. In this process, soil samples of known dry weight were extracted with a hot concentrated nitric acid-hydrofluoric acid mixture. The extract was reduced to dryness. dissolved in $0.1 \mathrm{M}$ nitric acid, and $10 \mathrm{~m} \ell$ was plated on a $\bar{i} \cdot \mathrm{cm}$ diam stainless steel plate. Samples were counted in a gas-flow proportional counter for the period of time required to obtain acceptable counting statistics. The method was sensitive to soil gross-alpha concentrations at the several $\mathrm{pCi} / \mathrm{g}$ level. The time required for analysis was on the order of $8 \mathrm{~h}$.

The second chemical process was a "complete" analysis for plutonium. It was used on approximateIf $15 \%$ of the collected soil samples for the purpose of confirming othe: methods and fur determining plutonium-a!pha to gross-alpha ratios. This chemistry was followed by pulse height analysis using silicon-barrier, solid-state detectors and a mult channel analyzer. Again, counting times were as long as necessaiy to obtain acceptable crunting statisiics. The method was sensitive to plutonium concentrations at the fractional $p(\mathrm{c} i \mathrm{~g}$ level. The ime required for analysis was on the order of $12 \mathrm{~h}$.

\section{A-3. High-Volume Air Sampler}

The high-volume air sampler operated on 110-120 VAC power and pulled approximately $32 \mathrm{cfm}$ across a 6 -in. by 9 -in. HV-70 filter media. The flow rate was measured by a visi-float flow meter attached to the discharge side of the sampler. The filter media were anaiyzed using "wide-beta" counters. These samplers are mounted in pairs on two wheeled trailers along with a gasoline powered electrical nenerator. 


\section{A-4. Portuble Air Sampler}

This air sampler is a small, semi-portable device with adjustable volume control operating on 110-120 VAC power. It was generally used with a $5.4 \cdot \mathrm{cm}$ diam $\mathrm{HV}-70$ filter media and sampled at $2 \mathrm{ctm}$. The ent ire device may be moved by a two-wheel dolly assembly attached to the motor housing. The flow rate is measured by a magnehelic meter attached to an orifice meter un the discharge side of the sampler. The filter media are analyzed using "wide-beta" counters.

\section{A-5. Alpha Survey Instrument}

This aipha survey instrument ising a LASLdesigned, two-wire air proportional probe, was used by health physics surveyors for field monitcing for alpha contamination. It has scales of $0-1000$, $0.10000,0-100000$, and $0-1000000$ counts/mir. Farphones allow the operator to hear individual pulses. On its most sensitive scale, it is used to determine the presence of personnel or equipment con. tamination.

\section{A-6. FIDLER/LAAFHA}

This system consists of a commercial Field Instrument for Detecting Low-Energy Radiation probe coupled to the Los Aiamos Field Pulse Heigh Analyzer. The former is a thin Nal crystul $11.5 \times 1$. $\mathrm{mr}$ :) optimized for the detection of luw-energy $x$ and gamma-rays. The latter is a portable, i-chant analyzer with variable channel capabilities sultainl for field $x$ - and gammu-ray spectriscopy on a gru level. Resulting data are reported as net counts pt minute in a channel centered on the plutonium 17 $\mathrm{keV} \times$ ray. From the data ohtained during thes cleanup operations, it appears that th FIDLER/LAFPHA is capable of distinguishin radioacisvity above soil background at a level on th order of 0.1 to $0.2 \mathrm{nCi} / \mathrm{g}$.

This instrument was used in three modes durin the cleanup. It was hand carried, at $-30 \mathrm{~cm}$ abor the ground, at a slow walking pace to define gros patterns of radioactivity and to dete" residtal hr spots. It was set on a stationary tripod, at $30 . \mathrm{cl}$ height, to deternine "wide-area" contaminatio levels. It was used on a stand at $5 \mathrm{~cm}$ height $11 \mathrm{HI}$ "small-area" measurements.

\section{A-7. Beta-Gamma Survey Instrument}

The beta-gamma portable survey instrument is five-scale ionization meter capable of measurir beta-gamma radiation. The following full sca ranges are available: $0-3,0-10,0-30,0-100$. and $300 \mathrm{mrem} / \mathrm{h}$.

\section{APPENDIX B SOIL SAMPLING TECHNIQUES}

Surface soils were taker at Leak 1 using a location pattern based on the preliminary FIDLER/LAFPHA survey (see Fig. 2). Samples were also taken along the drainage path of the area out to the edge of the canyon; Fig. 6 shows the isopleth map of the area as determined from the soil samples. The surface soil samples were taken using a simple hand scoop to half fill a $20 \times 20 \mathrm{~cm}$ self-sealing plastic bag with soil from no deeper than $5 \mathrm{~cm}$. The samring scoop was cleaned with alcoho: and distilled water between samples. Six hundred surface samples were collected and analyzed with the zinc sulfide system and the chemical procedures described in Appendix A.

correspondence between results was generally acceptable, most falling within a factor of two of each wher. Differences are attributable to in. homogeneities in the bulk sample from which 1 two separate aliquots were taken. Some sample du are given in Table B-I. In a recent cleanup operati using the same instruments and similar chemic procedures, the discrepancies were reduced by it ing the aliquot for chemical analysis from the $\mathrm{Z}_{n}$ counted sample.'

Two techniques were used for determining 1 depth distribution of the contaminant within the st profile. Core samples were taken by ham mering a: cm long. 2.4-cm diam, bevel-ended lic" pipe in the soil. The depth of the core was determined subtracting the length of emply pipe remainin Taking these samples required about is min per an This method raised somne question concernmp' possibility of smearing sulface combumation 
COMPARISUN . F VALUES FRUY THE ZnS SYSTEY WITH THOSE OF

THE ACID-IEACHING PRICFSS AND THF. TOTAL PLLTONILY CHEMICAL AVALYSIS

\begin{tabular}{|c|c|c|c|}
\hline Sample & $\begin{array}{c}p C i{ }^{\prime g} \\
\text { (Gross al pha) } \\
2 n s\end{array}$ & $\begin{array}{c}\text { pCi/g } \\
\text { (Gross Alpha) } \\
\text { Acid-Leaching } \\
\text { Process } \\
\end{array}$ & $\begin{array}{l}\text { PCi/g } \\
\text { (Pu-238 and } 239) \\
\text { Total plutonium } \\
\text { Chemical Analysis }\end{array}$ \\
\hline ]. & $<26$ & 6 & 3 \\
\hline 2 & $<2$ & 5 & 6 \\
\hline 3 & $<26$ & 6 & 4 \\
\hline 4 & $<2<$ & 35 & 39 \\
\hline 5 & $2 i$ & 5 & 0 \\
\hline 6 & 25 & 13 & 1 \\
\hline 7 & 2 & 32 & 34 \\
\hline 8 & $2^{*}$ & 9 & 37 \\
\hline 9 & $3:$ & 33 & 33 \\
\hline 10 & $3:$ & 43 & 43 \\
\hline 11 & $4 i$ & 14 & 18 \\
\hline 1.2 & $4^{-1}$ & 15 & 38 \\
\hline 13 & 54 & 23 & 20 \\
\hline$\vdots ;$ & 54 & 61 & 62 \\
\hline$: 5$ & $6:$ & 3 & 13 \\
\hline 16 & $6^{\prime \prime}$ & 36 & 45 \\
\hline 17 & 9.1 & 19 & 22 \\
\hline 18 & $9 d$ & 25 & 36 \\
\hline 19 & 98 & 34 & 83 \\
\hline 20 & 110 & 75 & 77 \\
\hline 21 & 110 & 52 & 124 \\
\hline 22 & 110 & 151 & 203 \\
\hline 23 & 120 & 37 & 112 \\
\hline 24 & 130 & 93 & 155 \\
\hline 25 & 130 & 37 & 104 \\
\hline 26 & 150 & 187 & 220 \\
\hline 27 & 160 & 69 & 76 \\
\hline 28 & 170 & 112 & 189 \\
\hline 29 & 180 & 56 & 77 \\
\hline 30 & 190 & 85 & 132 \\
\hline 31 & 230 & 198 & 190 \\
\hline 32 & 240 & 127 & 107 \\
\hline 33 & 290 & 120 & 256 \\
\hline 34 & 290 & 326 & 405 \\
\hline 35 & 350 & 95 & 154 \\
\hline 36 & 840 & 2010 & 2890 \\
\hline 37 & 920 & 404 & 655 \\
\hline 38 & 930 & 564 & 300 \\
\hline 39 & 930 & 1060 & 1090 \\
\hline 40 & 1750 & 1045 & 1177 \\
\hline 41 & 3340 & 1030 & 2030 \\
\hline 42 & 3600 & 1670 & 2950 \\
\hline 43 & 4000 & 3350 & 4450 \\
\hline 44 & 4520 & 3450 & 4239 \\
\hline 45 & 13400 & 12900 & 12200 \\
\hline 46 & 28700 & 26260 & 36600 \\
\hline 47 & 403000 & 372000 & 500000 \\
\hline
\end{tabular}


the entire length of the core by the passage of the pipe. The problem was investigated using a trenchprofile sampling technique. Basically, a soil profile was exposed by cutting a trench, then layers of the soil were carefuily sampled, removing ore layer to expose the next afte: each sample. The procedure required about $40 \mathrm{mi}$ : per trench profile.

Comparative data are offered in Table B-II. Larger increments of depth are reported for the core samples since smaller quantities of sample were available per unit depth. In most cases the core data do not reflect the same depth as the trench profile data, due to the difficulty in driving the core successfully through the rocky soil. The two sets of data compare well enough so that for the purpose of determining the presence of subsurface contamination over wide areas the easier and much faster coring method was acceptable.

Eighty cores were taken and analyzed to determine the distribution of the contaminants with depth. In general, less than the full $30 \mathrm{~cm}$ sample was obtained. In areas close to the leak, the radioactivity was observed to decrease rapidly with depth, but substantial radioactivity still remained at 30 $\mathrm{cm}$, indicating that a considerable depth of soil would have to be removed. In areas further from the source the cores showed more or less uniform concentrations over the depth of the core, indicating that the radioactivity had probably been laid down by silt deposited from runoff from frequent summer storms.

Finally, in the main drainage channel at fairly large distances from the source, crres showed anomalous high conr.ntrations separated by layers of low concentration. This was attributed to deposition from storm runoff where only the largest storms could carry the most radioactive soils that far from the source. Small storms accounted for the deposition of the less radioactive soils.

\section{REFERENCE}

1. A. J. Ahlquist, A. K. Stoker and C. J. Umbarger. "Recent Developments for Field Monitoring of Alpha-Emitting Contaminants in the Environment," to be published. 
TABLE B-I I

SOIL PROFILE DATA FOR COMPARISON OF SAMPLING METHODS

\begin{tabular}{|c|c|c|c|c|}
\hline \multicolumn{2}{|c|}{$\begin{array}{r}\text { Cores } \\
\end{array}$} & \multirow[b]{2}{*}{$\begin{array}{l}\text { Location } \\
\text { Number }\end{array}$} & \multicolumn{2}{|c|}{ Trenches } \\
\hline $\begin{array}{l}\text { PVC Pipe Core } \\
\text { pCi/ga }\end{array}$ & $\begin{array}{c}\text { Sample } \\
\text { Depth }(\mathrm{cm})\end{array}$ & & $\begin{array}{l}\text { Sample } \\
\text { Depth }\end{array}$ & $\begin{array}{c}\text { Trench Profile } \\
\text { pci/ga }\end{array}$ \\
\hline 4 & $0-8.5$ & 1 & $\begin{array}{r}0-2.5 \\
2.5-5.0 \\
5.0-7.5\end{array}$ & $\begin{array}{l}5 \\
3 \\
3\end{array}$ \\
\hline 13 & $0-7$ & 2 & $\begin{array}{r}0-2.5 \\
2.5-5.0\end{array}$ & $\begin{array}{r}4 \\
14\end{array}$ \\
\hline 58 & $0-5$ & 3 & $\begin{array}{r}0-2.5 \\
2.5-5.0\end{array}$ & $\begin{array}{l}21 \\
64\end{array}$ \\
\hline 29 & $5-10$ & & $\begin{array}{l}5.0-7.5 \\
7.5-10.0\end{array}$ & $\begin{array}{l}30 \\
60\end{array}$ \\
\hline 53 & $10-15$ & & $\begin{array}{l}10.0-12.5 \\
12.5-15.0 \\
15.0-17.5 \\
17.5-20.0 \\
20.0-22.5 \\
22.5-25.0\end{array}$ & $\begin{array}{r}63 \\
55 \\
26 \\
5 \\
6 \\
12\end{array}$ \\
\hline 54 & $0-6$ & 4 & $\begin{array}{r}0-2.5 \\
2.5-5.0 \\
5.0-7.5 \\
7.5-10.0 \\
10.0-12.5 \\
12.5-15.0 \\
15.0-17.5\end{array}$ & $\begin{array}{r}173 \\
33 \\
13 \\
5 \\
3 \\
6 \\
3\end{array}$ \\
\hline 37 & & 5 & $\begin{array}{r}0-2.5 \\
2.5-5.0\end{array}$ & $\begin{array}{l}34 \\
22\end{array}$ \\
\hline 80 & $5-10$ & & $\begin{array}{l}5.0-7.5 \\
7.5-10.0\end{array}$ & $\begin{array}{l}21 \\
20\end{array}$ \\
\hline 60 & $10-14$ & & $\begin{array}{l}10.0-12.5 \\
12.5-15.0 \\
15.0-17.5\end{array}$ & $\begin{array}{l}18 \\
28 \\
41\end{array}$ \\
\hline 513 & $0-6.5$ & 6 & $\begin{array}{r}0-2.5 \\
2.5-5.0 \\
5.0-7.5\end{array}$ & $\begin{array}{r}1300 \\
175 \\
53\end{array}$ \\
\hline 4 & $0-5$ & 7 & $\begin{array}{r}0-2.5 \\
2.5-5.0\end{array}$ & $\begin{array}{r}8 \\
18\end{array}$ \\
\hline 4 & $5-10$ & & $\begin{array}{l}5.0-7.5 \\
7.5-10.0\end{array}$ & $\begin{array}{r}15 \\
9\end{array}$ \\
\hline 3 & $10-15$ & & $\begin{array}{l}10.0-12.5 \\
12.5-15.0\end{array}$ & $\begin{array}{l}11 \\
20\end{array}$ \\
\hline 6572 & $0-5$ & 8 & $\begin{array}{r}0-2.5 \\
2.5-5.0 \\
5.0-7.5 \\
7.5-10.0 \\
10.0-11.0\end{array}$ & $\begin{array}{r}4640 \\
14100 \\
11700 \\
3000 \\
2400\end{array}$ \\
\hline
\end{tabular}

ata are the average of the zir.c sulfide and acid leach values. 